\title{
Growth and clorophyll content dynamics of Winter Wheat (Triticum aestivum L.) in different cropyear
}

\author{
Enikő Vári \\ University of Debrecen, Centre for Agricultural and Applied Economic Sciences, Institute of Crop Science, Faculty of Agricultural and \\ Food Sciences and Environmental Management, Debrecen \\ eniko.vari@gmail.com
}

\section{SUMMARY}

The experiments were carried out at the Látókép experimental station of the University of Debrecen on chernozem soil in a long term winter wheat experiment in the season of 2011 and 2012 in triculture (pea-wheat-maize) and biculture (wheat-maize) at three fertilisation levels (control, $N_{50}+P_{35} K_{40}, N_{150}+P_{105} K_{120}$ ). Two different cropyears were compared (2011 and 2012).

The research focused on the effects of forecrop and fertilisation on the Leaf Area Index, SPAD values and the amount of yield in two different cropyears. We wanted to find out how the examined parameters were affected by the cropyear and what the relationship was between these two parameters and the changes of the amount of yield.

Examining the effects of growing doses of fertilizers applied, results showed that yields increased significantly in both rotations until the $N_{150}+P K$ level in 2011 and 2012. By comparing the two years, results show that in 2011 there was a greater difference in yields between the rotations (7742 $\mathrm{kg} \mathrm{ha}^{-1}$ at $N_{150}+P K$ in the biculture and $9830 \mathrm{~kg} \mathrm{ha}^{-1}$ at $N_{150}+P K$ in the triculture). Though wheat yields following peas were greater in 2012, results equalized later on at $N_{150}+P K$ levels $\left(8109-8203 \mathrm{~kg} \mathrm{ha}^{-1}\right)$.

Due to the favorable agrotechnical factors, the leaf and the effects of the treatments grown to a great extent in 2011, while in 2012 the differences between treatments were moderate. Until the $N_{150}+P K$ level, nitrogen fertilisation had a notable effect on the maximum amount of SPAD values (59.1 in the case of the biculture and 54.0 in the triculture).

The highest SPAD values were measured at the end of May (during the time of flowering and grain filling) in the biculture. In the triculture, showed high SPAD values from the beginning. The same tendency could be observed in the 2012 cropyear, although increasing doses of fertilizers resulted in higher SPAD values until $N_{150}+P K$ level only from the second measurement. Maximum SPAD values were reached at the end of May in both crop rotation system

Keywords: winter wheat, crop year, growth dynamics, yield

\section{ÖSSZEFOGLALÁS}

A vizsgálatokat a Debreceni Egyetem AGTC Látóképi Kisérleti Telepén beállitott tartamkisérletben végeztük, trikultúra (borsó-búzakukorica) és bikultúra (búza-kukorica) vetésváltásban, 3 tápanyagszinten (kontroll, $N_{50}+P_{35} K_{40}, N_{150}+P_{105} K_{120}$ ) öszi búzánál mészlepedékes csernozjom talajon. Két eltérö évjáratot hasonlitottunk össze $(2011,2012)$.

A kisérletben az elövetemények és a mütrágyaadagok hatását vizsgáltuk az öszi búza levélfelületi indexére, SPAD értékeire, valamint a termés mennyiségére két eltérö évjárat esetén. Arra kerestük a választ, hogy a vizsgált paraméterek alakulását hogyan befolyásolja az évjárat, valamint, hogy e két mutató milyen összefüggésben van a termés mennyiségének változásával.

A mütrágyázás hatását vizsgálva 2011-ben és 2012-ben, mindkét vetésváltásnál megállapitható, hogy a növekvö trágyaszintek hatására szignifikánsan növekedtek a termés mennyiségek az $N_{150}+$ PK tápanyagkezelésig. A két évet összehasonlítva megállapitható, hogy 2011-ben nagyobb különbségeket kaptunk az eltérö vetésváltás során a terméseredményekben (bikultúra az $N_{150}+P K$-nál $7742 \mathrm{~kg} / \mathrm{ha}$, trikultúra az $N_{150}+P K-$ nál: $9830 \mathrm{~kg} / \mathrm{ha}$ ). 2012-ben ugyan több volt a termés mennyisége a borsó után vetett búza állományoknak, de az $N_{150}+P K$ tápanyagszintnél már kiegyenlitödtek a termésmennyiségek (8109-8203 kg/ha).

Amíg 2011-ben a kedvezö agrotechnikai tényezök hatására sokkal nagyobb levélfelület alakult ki (virágzás és a termékenyülés idején 1,3-4,2 $\mathrm{m}^{2} / \mathrm{m}^{2}$ ), és sokkal eröteljesebben jelentkeztek a kezelések hatásai, addig 2012-ben a kezelések közötti különbségek elhalványultak (virágzás és a termékenyülés idején $2-3,7 \mathrm{~m}^{2} / \mathrm{m}^{2}$ ).

Mindkét elővetemény után a $N$-mütrágyázásnak az $N_{150}+P K$ kezelésig jelentős hatása volt a SPAD-értékek maximumára (bikultúránál: 59,1; trikultúránál: 54,0). A május végi mérés esetén (a virágzás és termékenyülés időszakában) kaptuk a legnagyobb SPAD-értékeket bikultúrában. Trikultúrában azonban már az elsö mérés során magas SPAD-értékeket mértünk. A 2012-es tenyészévben is hasonló tendencia volt megfigyelhetö. A második méréstöl tapasztaltuk, hogy a növekvö tápanyagszintek hatására szignifikánsan nagyobb SPAD-értékeket kapunk, $N_{150}+$ PK kezelésig. A virágzás és termékenyülés idöszakában kaptuk a legnagyobb SPAD-értékeket tri- $(35,5-58,5)$ és bikultúrában $(56,4-59,2)$ egyaránt.

Kulcsszavak: öszi búza, évjárat, növekedési dinamika, termés

\section{REVIEW OF SCIENTIFIC LITERATURE}

Some of the biggest challenges in crop production are environmental changes caused by lack of available water and the decrease of ground water (Efeoğlu et al., 2009). Global climate change - temperature rising and inadequate distribution of precipitation over time - responsible for drought is expected to result in yield loss in crop production (Campos et al., 2004). According to Pepó (2002) the biggest risk factors of wheat production are today's extreme weather conditions.

SPAD chlorophyll indicator is a widely known tool amongst several other existing used to forecast yield (Le Bail et al., 2005). Chlorophyll content of the leaves 
provides information on the physiological condition of the plant (Carter, 1994) and there is a strong relationship between SPAD values, nitrogen and chlorophyll content of the leaves (Wood et al., 1993; Cartelat et al., 2005; Hu et al., 2010;).

Another important indicator is the leaf area index (LAI) determining the amount of yield. According to Ragasits (1998), one half of the dry material incorporated into the grain comes from the assimilation during the ripening process and the other half is translocated from various parts of the plant. Sugár and Berzsenyi (2009) found differences in LAI values caused by nitrogen supply in 2007 and 2008 as well. The lowest LAI values were measured in the $\mathrm{N}_{0}$ treatment which significantly increased at level $\mathrm{N}_{80}$ and reached the maximum - in line with seasonal dynamics - at $\mathrm{N}_{160}$ and $\mathrm{N}_{240}$ levels. Knowledge of the changes of leaf coverage over time and space is needed to understand the growth, development and yield formation of wheat (Yang et al., 2007).

\section{MATERIALS AND METHODS}

The experiments were carried out at the Látókép experimental station of the University of Debrecen on chernozem soil in a long term winter wheat experiment in the season of 2011 and 2012 in triculture (peawheat-maize) and biculture (wheat-maize) at three fertilisation levels (control, $\mathrm{N}_{50}+\mathrm{P}_{35} \mathrm{~K}_{40}, \mathrm{~N}_{150}+\mathrm{P}_{105} \mathrm{~K}_{120}$ ). The wheat variety used in the long-term trial was GK Csillag. The soil of the research site is plain and homogen, its genetic soil type is calciferous chernozem. The soil-physical category of the soil is loam, its $\mathrm{pH}$ value is almost neutral, phosphorus supply is medium, and potassium supply is medium-good. Humus content is medium, the thickness of humus layer is about $80 \mathrm{~cm}$. Estimated depth to groundwater is $3-5 \mathrm{~m}$.

Two different cropyears were compared. A mobile Soil Plant Analysis Development chlorophyll indicator (SPAD-502 Plus, Konica Minolta) was used to determine nitrogen supply of wheat. During the cropyear, measurements were applied four times in 2011 (30 March, 26 April, 24 May, 21 June) and in 2012 (23 March, 19 April, 22 May, 25 June) and this meant thirty measurements by repetition. In every case, the leaf area was determined by the SunScan Canopy Analysis Systems (SS1) mobile indicator, measurements were applied four times in 2011 (30 March, 26 April, 24 May, 21 June) and six times in 2012 (23 March, 19 April, 9 May, 22 May, 14 June, 25 June) Eight measurements were applied by repetition.

A contrast could be observed in the weather of the 2010/2011 cropyear; a wet period from October till December and a dry season between January and June. Regarding the temperature, October, December and February were cooler than the average, while the rest of the year was warmer compared with the average of the prior 30 years, which had a positive impact on the development of winter wheat.

In the case of the 2011/2012 growing year, the amount of precipitation was higher only in December, May and June compared with the average over a period of time. Meteorological conditions regarding the temperature were optimal considering the development of wheat, although October and November were cooler compared with the average over a period of time (table 1).

Table 1 .

Meteorological parameters in the vegetation period of winter wheat (precipitation, mean monthly temperature) (Debrecen, 2011-2012)

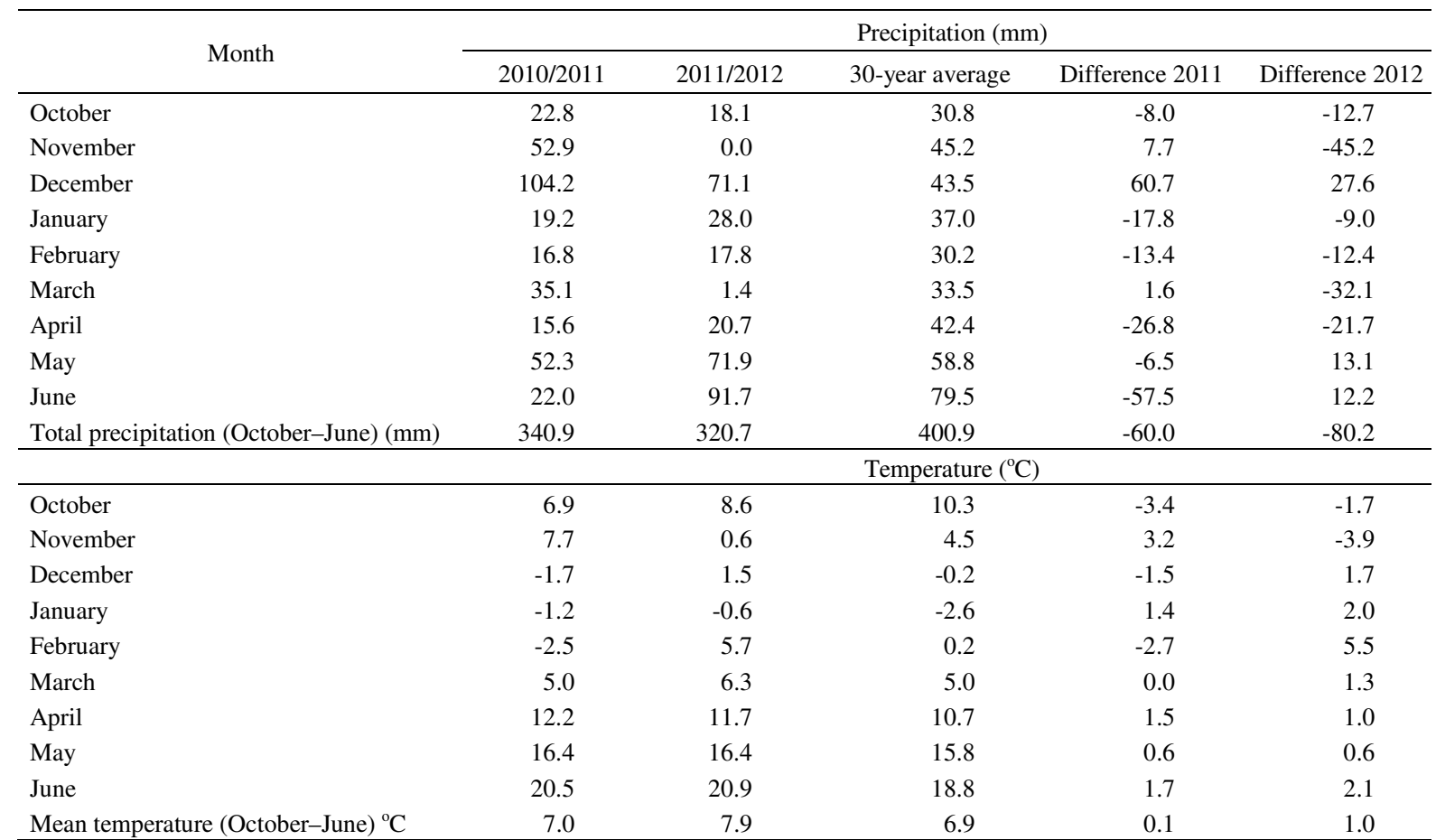




\section{RESULTS AND DISCUSSION}

The research focused on the effects of forecrop and fertilisation on the Leaf Area Index, SPAD values and the amount of yield in two different cropyears.

We wanted to find out how the examined parameters were affected by the cropyear and what the relationship was between these two parameters and the changes of the amount of yield.

\section{The yield of winter wheat}

Comparing maximum yields of wheat following corn and peas in 2011, it can be stated that the yields of wheat in triculture rotations were $2088-4615 \mathrm{~kg} \mathrm{ha}^{-1}$ higher than the ones in the biculture at the same nutrition levels. Examining the effects of growing doses of fertilizers applied, results showed that yields increased significantly in both rotations until the $\mathrm{N}_{150}+\mathrm{PK}$ level (figure 1).

The tendency was the same in 2012 and, besides, statistically-proven positive impacts of fertilisation and crop rotation were also shown this year. By comparing the two years, results show that in 2011 there was a greater difference in yields between the rotations $\left(7742 \mathrm{~kg} \mathrm{ha}^{-1}\right.$ at $\mathrm{N}_{150}+\mathrm{PK}$ in the biculture and $9830 \mathrm{~kg} \mathrm{ha}^{-1}$ at $\mathrm{N}_{150}+\mathrm{PK}$ in the triculture). Though wheat yields following peas were greater in 2012, results equalized later on at $\mathrm{N}_{150}+$ PK levels (8109-8203 $\left.\mathrm{kg} \mathrm{ha}^{-1}\right)$.

Figure 1: Effect of fertilisation on the yield of the winter wheat in biculture and triculture (Debrecen, 2011-2012)

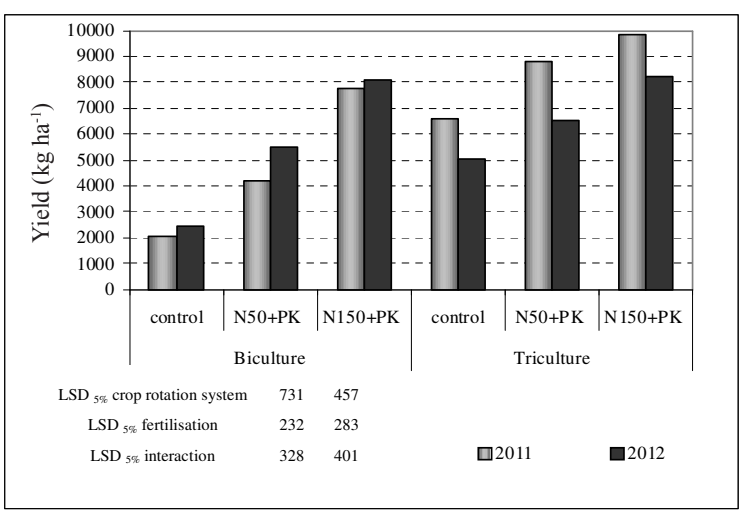

\section{The development of leaf area of wheat}

Grain yield and the volume of phytomass produced are altered by both the leaf area and its dynamics so we measured the leaf area per $1 \mathrm{~m}^{2}$ and illustrated its dynamics. At the time of the first measurement in 2011, the Leaf Area Index showed significant differences between the control and the others doses of nitrogen, in both rotation system however $\left(0.3-1.1 \mathrm{~m}^{2} \mathrm{~m}^{-2}\right)$, in 2012 at the first measurement (at the end of March) irrespectively of plant nutrition and forecrop, the differences between LAI were rather small $\left(0.2-0.3 \mathrm{~m}^{2} \mathrm{~m}^{-2}\right.$ ) (figure $2-3)$.
Figure 2: Effect of crop year, fertilisation and forecrops on

Leaf Area Index (LAI) of winter wheat (Debrecen, 2011)

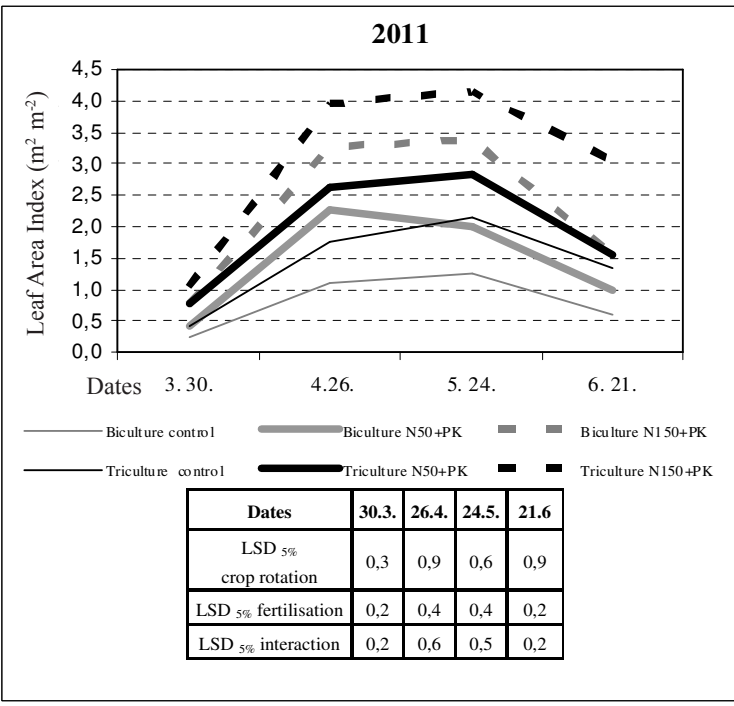

Figure 3: Effect of crop year, fertilisation and precrops on Leaf Area Index (LAI) of winter wheat (Debrecen, 2012)

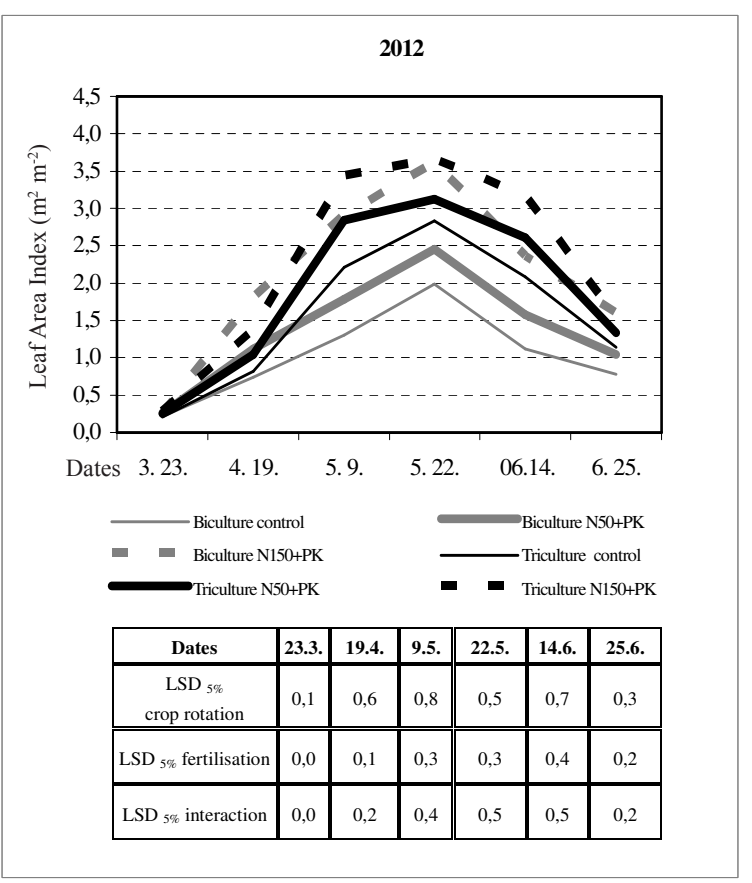

At the time of the following measurements, treatments resulted in significant differences in both crop years, however, positive effects of previous cropping and increased doses of fertilizers were stronger due to favorable weather conditions for wheat in 2011.

Regarding the changes of LAI over time, a significant increase could be experienced from the time of flowering and grain filling (the end of May) irrespectively of plant nutrition and previous crop. This was the point where the maximum level of leaf canopy was reached but showed a decreasing tendency afterwards. The difference is in the shape of the curves. Due to the favorable 
agrotechnical factors, the leaf area $\left(1.3\right.$ and $4.2 \mathrm{~m}^{2} \mathrm{~m}^{-2}$ at the time of flowering and grain filling) and the effects of the treatments grown to a great extent in 2011, while in 2012 the differences between treatments were moderate ( 2 and $3.7 \mathrm{~m}^{2} \mathrm{~m}^{-2}$ at the time of flowering and grain filling).

Increasing doses of fertilizers significantly enlarged the leaf area of winter wheat until the level of $\mathrm{N}_{150}+\mathrm{PK}$. By comparing the rotation systems, the leaf area of wheat was larger after peas, but this difference was not significant at any time of the measurement which fact can be proved by statistics. When setting the cropyears together, it can be concluded that wheat stands in 2011 kept their leaf areas much longer and values were between 0.6 and $3.1 \mathrm{~m}^{2} \mathrm{~m}^{-2}$ even at the time of the last measurement. Accordingly, vegetative development of winter wheat was considerably determined by weather conditions.

\section{The development of SPAD values of wheat}

At the time of the first measurement in 2011, irrespectively of plant nutrition and previous crop, the differences between SPAD values were rather small (41.3 and 54.0), however, the second measurement showed significant differences between the control, the $\mathrm{N}_{50}+\mathrm{PK}$ and the $\mathrm{N}_{150}+\mathrm{PK}$ levels in both rotation systems. Until the $\mathrm{N}_{150}+\mathrm{PK}$ level, nitrogen fertilisation had a notable effect on the maximum amount of SPAD values (59.1 in the case of the biculture and 54.0 in the triculture). It was a difference. The highest SPAD values were measured at the end of May (during the time of flowering and grain filling) in the biculture. In the triculture, on the other hand, showed great SPAD values from the beginning. However, SPAD values in winter wheat stands following peas were significantly lower than the ones following corn (55.8-59.1).

The same tendency could be observed in the 2012 cropyear, although increasing doses of fertilizers resulted in greater SPAD values until $\mathrm{N}_{150}+\mathrm{PK}$ level only from the second measurement. Beneficial effects of crop rotation were shown this year since SPAD results increased notably in triculture in the cases of each treatment. Maximum SPAD values were reached at the end of May in both crop rotation system (figure 4.).

Figure 4: Effect of crop year, fertilisation and forecrops on dynamics of SPAD-values of winter wheat (Debrecen, 2011-2012)
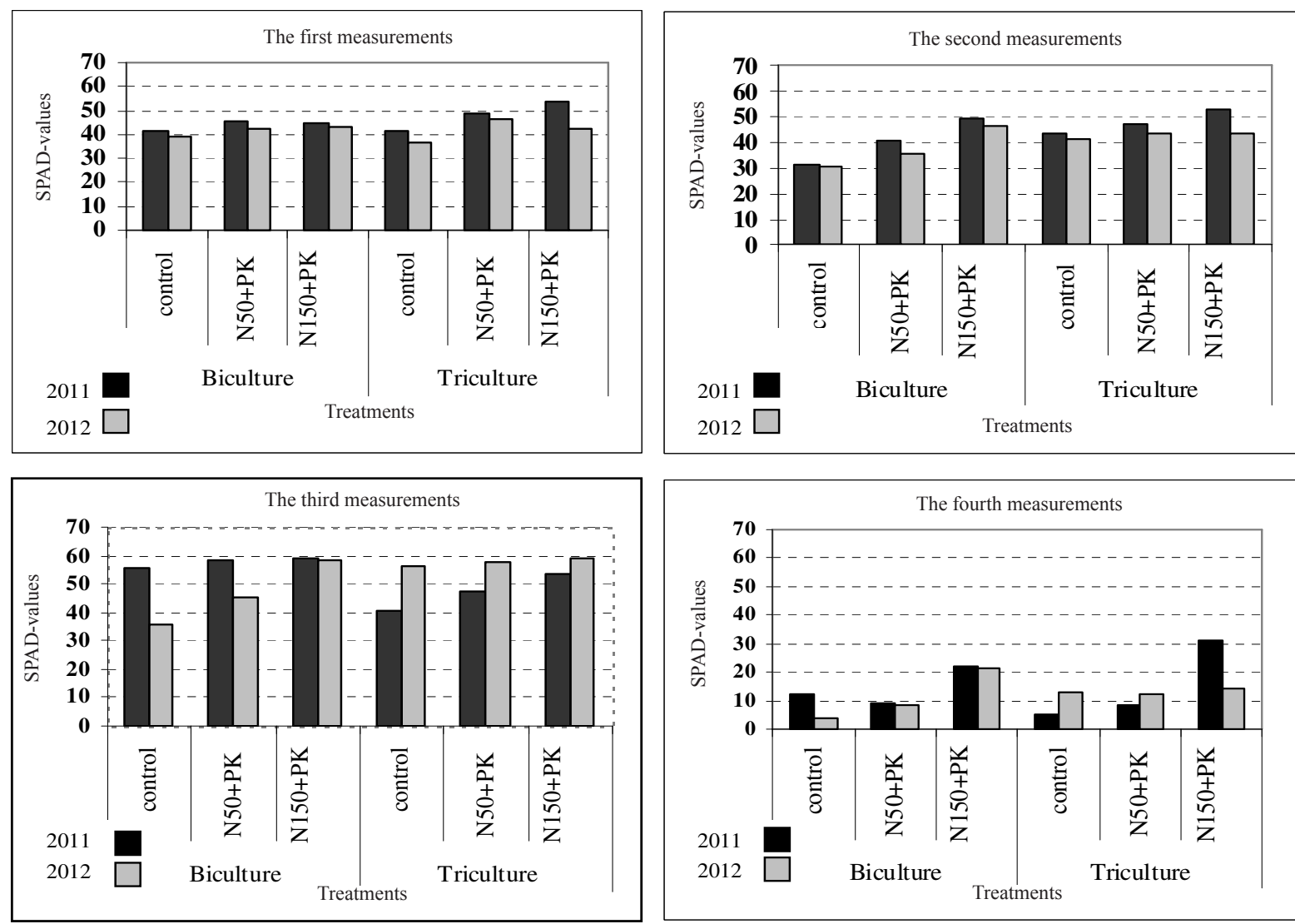

\section{CONCLUSIONS}

To sum it up, it is safe to say that different levels of fertilizer doses and crop rotation had a considerable impact on the dynamics and maximum values of the

leaf area, SPAD values and yields as well. These results have confirmed that the leaf area and the SPAD-values have altogether resulted in the production of maximum grain yields. These analysis makes it possible to predict the yield of winter wheat. 


\section{ACKNOWLEDGEMENTS}

The realization of this project is supported by the European Union and Hungary in the frames of the high priority National Excellence Program TÁMOP 4.2.4. A/2-11-1-2012-0001 - Elaborating and Operating an Inland Student and Researcher Personal Support System convergence program.

\section{REFERENCES}

Campos, H.-Cooper, M.-Habben, J. E.-Edmeades, G. O.-Schussler J. R. (2004): Improving drought tolerance in maizea view from industry. Field Crops Research. 90. 1: 19-34.

Cartelat, A.-Cerovic, Z. G.-Goulas, Y.-Meyer, S.-Lelarge, C.-Prioul, L.-Barbottin, A.-Jeuffroy, M. H.-Gate, P.-Agati, G.-Moya, I. (2005): Optically assessed contents of leaf polyphenolics and chlorophyll as indicators of nitrogen deficiency in wheat (Triticum aestivum L.). Field Crops Research.

Carter, G. A. (1994): Ratios of leaf reflectances in narrow wavebands as indicators of plant stress. International Journal of Remote Sensing. 15. 3: 697-703.

Efeoğlu, B.-Ekmekçi, Y.-Çiçek, N. (2009): Physiological responses of three maize cultivars to droughtstress and recovery. South African Journal of Botany. 75. 2: 443.

Hu, Hao-Bai, Youlu-Yang, Liping-Lu, Yanli-Wang, Lei-Wang, HeWang, Zhiyong (2010): Diagnosis of nitrogen nutrition in winter wheat (Triticum aestivum L.) via SPAD-502 and GreenSeeker. Chinese Journal of Eco-Agriculture. 18. 4: 748-752.
Le Bail, M.-Jeuffroy, M. H.-Bouchard, C.-Barbottin, A. (2005): Is it possible to forecast the grain quality and yield of different varieties of winterwheat from Minolta SPAD meter measurements? European Journal of Agronomy. 23. 4: 379-391.

Pepó P. (2002): A hazai őszi búzatermesztés helyzete és fejlesztési lehetőségei. Gyakorlati Agrofórum. 13. 9: 2-5.

Ragasits I. (1998): Búzatermesztés. Mezőgazda Kiadó. Budapest. 61-68.

Sugár E.-Berzsenyi Z. (2009): Őszi búzafajták növekedésdinamikája és termésprodukciója eltérő N-tápelemszinteken. Tartamkísérletek jelentősége a növénytermesztés fejlesztésében. Jubileumi tudományos konferencia. Martonvásár. 2009. október 15. 159-164.

Wood, C. W.-Reeves, D. W.-Himelrick, D. G. (1993): Relationships between chlorophyll meter readings and leaf chlorophyll concentration, N status, and crop yield. A review. Proceedings Agronomy Society of New Zealand. 23: 1-9.

Yang, P.-Wu, W. B.-Tang, H. J.-Zhou, Q. B.-Zou, J. Q.-Zhang, L. (2007): Mapping spatial and temporal variations of leaf area index for winter wheat in North China. Agricultural Sciences in China. 6. 12: 1437-1443. 
